\title{
Bullying di Sekolah dan Dampaknya bagi Masa Depan Anak
}

\author{
Ahmad Baliyo Eko Prasetyo*
}

\begin{abstract}
This paper aims at reviewing bullying at schools, including its definitions, characteristics, forms and factors preceding it. More specifically, this paper discusses the effects of bullying on children's future. According to literatures and some various researches, bullying in childhood and in school days allegedly becomes one of main factors that caused psychological disorders in their adulthood. Some of recorded disorders that are related to long-term impact of bullying at school days are Post-Traumatic Stress Disorder (PTSD), depression, lack of confidence, and withdrawal. Eventually, this paper will propose the ways and methods in solving and preventing bullying and its impacts.
\end{abstract}

Keywords: bullying, bullying at schools, Post-Traumatic Stress Disorder (PTSD), bullying prevention.

\footnotetext{
* Penulis adalah alumnus Fakultas Psikologi dan Ilmu Sosial Budaya (FPSB) UII Yogyakarta, praktisi hypnotherapy dan anggota Indonesian Board of Hypnotherapy (IBH).
}

\section{A. Pendahuluan}

Kekerasan dalam dunia pendidikan adalah fakta yang sudah sering terjadi. Di Jakarta, hampir tiap pekan ada tawuran pelajar yang karena seringnya, peristiwa tersebut sudah tidak lagi menarik bagi para pencari berita. Beberapa waktu lalu, dunia pendidikan tanah air sempat juga dihebohkan oleh kasus Geng Nero yang beranggotakan para pelajar putri di Pati Jawa Tengah. Geng pelajar putri ini menjadi terkenal seantero negeri setelah video rekaman penganiayaan mereka terhadap pelajar putri lainnya beredar di internet dan diangkat secara luas oleh media massa nasional. Fakta tersebut kemudian menguak salah satu sisi gelap pergaulan pelajar, di mana ternyata kasus serupa tidak hanya terjadi di Pati, tetapi banyak terjadi juga di beberapa kota lain, dan terlebih di kota-kota besar. Fakta mengejutkan tersebut sontak membuka mata banyak pihak tentang bentuk lain dari kekerasan di sekolah dan dunia pendidikan pada umumnya.

Selama ini, ketika berbicara mengenai kekerasan pelajar, topik yang seringkali muncul adalah tentang tawuran pelajar. Padahal sebenarnya ada bentuk lain kekerasan di sekolah yang jarang muncul ke permukaan tetapi dapat menimbulkan dampak yang jauh lebih serius, yakni bullying. Kasus penganiayaan pelajar anggota Geng Nero terhadap pelajar lainnya seperti disebutkan di awal tulisan ini adalah termasuk dalam kategori bullying.

Tulisan ini hendak membahas bullying beserta karakteristiknya, perbedaannya dengan bentuk perilaku kekerasan lain, dampaknya serta aksi apa saja yang bisa dilakukan untuk mencegah dan menangani bullying, baik korban maupun pelaku.

\section{B. Pembahasan \\ 1. Definisi Bullying}

Secara harfiah, kata bully berarti menggertak dan mengganggu orang yang lebih lemah. Istilah bullying kemudian digunakan untuk menunjuk perilaku agresif seseorang atau sekelompok orang yang dilakukan secara berulang-ulang terhadap orang atau sekelompok orang lain yang lebih lemah untuk menyakiti korban secara fisik maupun mental. Bullying bisa berupa kekerasan dalam bentuk fisik (misal: menampar, memukul, menganiaya, menciderai), verbal (misal: mengejek, mengolokolok, memaki), dan mental/ psikis (misal: memalak, mengancam, mengintimidasi, mengucilkan) atau gabungan di antara ketiganya (Olweus, 1993: 24).

Berdasarkan definisi tersebut, bullying terjadi 
karena dua hal: pertama, adanya ketidakseimbangan kekuatan antara pelaku bullying yang lebih kuat dan target(korban) yang lebih lemah. Ketidakseimbangan kekuatan ini bisa berupa ukuran badan, kekuatan fisik, jumlah pelaku versus korban, kepandaian bicara, gender (jenis kelamin), status sosial, dan perasaan lebih superior. Unsur ketidakseimbangan kekuatan dan intensitas yang berulang-ulang inilah yang membedakan bullying dengan bentuk kekerasan lainnya. Dalam konflik antara dua orang atau antar kelompokyang kekuatannya sama(termasuk tawuran massal antar pelajar), masing-masing memiliki kekuatan berimbang dan memiliki kemampuan untuk saling menyerang atau menawarkan solusi dan kompromi untuk menyelesaikan masalah. Dalam kasus bullying, ketidakseimbangan kekuatan antara pelaku bullying dan korbannya menghalangi keduanya untuk menyelesaikan konflik mereka sendiri, sehingga perilaku kekerasan ini terjadi berulang-ulang. Dengan demikian, penyelesaian bullying perlu kehadiran pihak ketiga. Sebagai contoh, seorang siswa yang mendapat perlakuan bullying dari teman sekolahnya yang lebih kuat, perlu bantuan orang dewasa seperti guru atau orangtua untuk menolongnya. Kedua, adanya penyalahgunaan ketidakseimbangan kekuatan tersebut untuk kepentingan pelaku dengan cara mengganggu, menyerang secara berulang kali, atau dengan cara mengucilkan orang lain. Kepentingan tersebut bisa berupa keinginan untuk menunjukkan kekuasaan atau superioritas, kepentingan ekonomi, atau hanya sekedar memenuhi kepuasan diri melihat orang lain tunduk padanya (Olweus, 1993: 25).

Bullying dapat terjadi di lingkungan mana saja di mana terjadi interaksi sosial antar manusia, antara lain di sekolah (school bullying), kampus, tempat kerja (workplace bullying), dunia maya (cyber bullying), lingkungan politik (political bullying), lingkungan militer (military bullying), dan lingkungan masyarakat (preman, geng motor). Dalam hal ini, bullying di sekolah adalah kasus yang sering dilupakan. Padahal, bullying di sekolah dapat menyebabkan efek yang sangat serius baik dalam jangka pendek maupun jangka panjang bagi para korbannya. Dalam jangka pendek bullying dapat menimbulkan perasaan tidak aman, takut pergi ke sekolah, merasa terisolasi, perasaan harga diri yang rendah, depresi atau bahkan menderita stress yang dapat berakhir dengan bunuh diri bagi si korban. Sedangkan dalam jangka panjang, korban bullying dapat menderita masalah gangguan emosional dan perilaku (Indonesian Anti-Bullying, http:// id.wordpress.com/tag/bullying/).

Fakta-fakta berikut barangkali cukup membuktikan dampak bullying yang begitu serius dan mengkhawatirkan. Pada tahun 2005 lalu, seorang gadis remaja berusia 13 tahun siswi SMP 10 Bantar Gebang, Bekasi, ditemukan tergantung di kamar mandi rumahnya. Gadis tersebut diyakini mengakhiri hidupnya karena merasa malu sering diejek teman-teman sekelasnya sebagai anak tukang bubur. Kasus yang hampir sama dialami oleh gadis bernama Linda Utami (15 tahun), siswi kelas 2 di SLTPN 12 Jakarta. Ia ditemukan menggantung diri di kamar tidurnya. Tindakan tersebut diduga kuat terjadi karena depresi akibat sering diejek teman-temannya di sekolah lantaran ia tidak naik kelas (http://mfahmia2705.blogspot.com/2007/06/ budaya-bullying-di-sekitar-kita.html).

Mengapa kasus bullying di sekolah ini kurang banyak mendapat perhatian hingga akhirnya jatuh korban? Pertama, efeknya tidak tampak secara langsung, kecuali bullying dalam bentuk kekerasan fisik. Ini pun sebagian besar tidak terendus karena banyak korban yang tidak mau melaporkan kekerasan yang dialaminya, entah karena takut, malu, diancam atau karena alasan-alasan lain. Kedua, banyak kasus bullying yang secara kasatmata tampak seperti bercandaan biasa khas anak-anak sekolah atau remaja yang dikira tidak menimbulkan dampak yang serius. Ejekan-ejekan dan olok-olokan verbal termasuk dalam kategori ini. Banyak orangtua dan guru yang mengira bahwa teguran saja mungkin sudah cukup untuk menyelesaikan bercandaan bocah-bocah itu. Padahal luka psikis dan emosional yang dialami korban kekerasan verbal itu jauh lebih dalam dan menyakitkan. Ketiga, sebagian orangtua dan guru masih belum memiliki pengetahuan yang memadai mengenai bullying dan dampaknya bagi kehidupan anak. Sehingga sebagian orangtua dan guru benarbenar tidak tahu bahwa ada masalah serius di sekitar mereka.

\section{Agresi dan Bullying}

Bullying sebenarnya adalah salah satu dari bentuk perilaku agresi. Agresi merupakan perilaku yang dimaksudkan menyakiti orang lain, baik secara fisik maupun psikis. Dalam hal ini, jika menyakiti orang lain karena unsur ketidaksengajaan, maka 
perilaku tersebut bukan dikategorikan perilaku agresi. Rasa sakit akibat tindakan medis misalnya, walaupun sengaja dilakukan bukan termasuk agresi. Sebaliknya, niat menyakiti orang lain meski tidak berhasil, dapat dikategorikan sebagai perilaku agresi. Pengertian agresi merujuk pada perilaku atau bentuk keinginan (drive-motivation) yang dimaksudkan untuk membuat objeknya mengalami bahaya atau kesakitan. Agresi adalah fenomena kompleks yang terdiri dari sejumlah perilaku dari jenis yang lebih khusus (Hall \& Lindzey, 1993).

\section{a. Faktor-faktor Agresi}

Beberapa teori agresi mengatakan bahwa penyebab utama munculnya perilaku agresi adalah terhalangnya seseorang dalam mencapai tujuan, kebutuhan, keinginan, atau pengharapannya. Frustrasi yang muncul ini disebabkan adanya faktor dari luar yang begitu kuat menekan sehingga muncul perilaku agresi. Bandura menyatakan bahwa perilaku agresi merupakan hasil dari proses belajar sosial melalui pengamatan terhadap dunia sosial (Soedardjo \& Fadilla, 1998).

Media, baik cetak maupun elektronik, tidak kalah penting dalam mendukung terbentuknya perilaku agresi. Tayangan kekerasan dapat menimbulkan rangsangan dan memungkinkan individu yang melihatnya, terlebih mereka yang berusia muda, untuk meniru model kekerasan seperti yang ditayangkan. Situasi yang setiap hari menampilkan kekerasan yang beraneka ragam, sedikit demi sedikit akan memberikan penguatan bahwa hal itu merupakan hal yang menyenangkan atau hal yang biasa dilakukan (Davidoff, Ronald, et. al., 1990; Soedardjo \& Fadilla, 1998). Dengan menyaksikan adegan kekerasan tersebut terjadilah proses belajar dari model (orang) yang melakukan kekerasan di televisi sehingga akan memunculkan perilaku agresi.

Selain itu, beberapa penelitian menemukan bahwa perilaku agresi ternyata juga menular. Ada rangsanganperilakuagresiyangdisebabkanseringnya seseorang melihat tayangan perilaku agresi melalui televisi atau membaca surat kabar yang memuat hasil perilaku agresi, seperti pembunuhan, tawuran massal, dan penganiayaan. Keluarga, lingkungan, dan teman bergaul yang memiliki perilaku agresi juga bisa menularkan perilaku tersebut (Davidoff, Ronald, et. al., 1990).

Secara umum, ada beberapa faktor yang dapat memicu perilaku agresif, diantaranya adalah:

\section{Faktor Biologis}

Menurut Davidoff (1990), ada beberapa faktor biologis yang mempengaruhi perilaku agresi:

a. Gen tampaknya berpengaruh pada pembentukan sistem syaraf otak yang mengatur perilaku agresi. Dari penelitian yang dilakukan terhadap binatang, mulai dari yang sulit sampai yang paling mudah dipancing amarahnya, faktor keturunan tampaknya membuat hewan jantan yang berasal dari berbagai jenis lebih mudah marah dibandingkan betinanya.

b. Sistem otak yang tidak terlibat dalam agresi ternyata dapat memperkuat atau menghambat sirkuit syaraf yang mengendalikan agresi. Pada hewan sederhana marah dapat dihambat atau ditingkatkan dengan merangsang sistem limbic (daerah yang menimbulkan kenikmatan pada manusia) sehingga muncul hubungan timbal balik antara kenikmatan dan kekejaman. Orang yang berorientasi pada kenikmatan akan sedikit melakukan agresi sedangkan orang yang tidak pernah mengalami kesenangan, kegembiraan atau santai cenderung untuk melakukan tindakan agresi.

c. Kimia darah. Kimia darah (khususnya hormon seks yang sebagian ditentukan faktor keturunan) juga dapat mempengaruhi perilaku agresi. Dalam suatu eksperimen, ilmuwan menyuntikkan hormon testosteron pada tikus dan beberapa hewan lain (testosteron merupakan hormon androgen utama yang memberikan ciri kelamin jantan). Tikus-tikus tersebut tak lama kemudian berkelahi semakin sering. Sewaktu testosteron dikurangi hewan tersebut menjadi lembut. Kenyataan menunjukkan bahwa anak banteng jantan yang sudah dikebiri (dipotong alat kelaminnya) akan menjadi jinak. Sedangkan pada wanita yang sedang mengalami masa haid, kadar hormon kewanitaan yaitu estrogen dan progesterone menurun jumlahnya. Akibatnya, pada masa-masa haid ini wanita cenderung mudah tersinggung, gelisah, tegang dan mudah bermusuhan. Selain itu banyak wanita yang melakukan pelanggaran hukum (melakukan tindakan agresi) pada saat berlangsungnya siklus haid ini. 


\section{Lingkungan}

a. Kemiskinan. Bila seorang anak dibesarkan dalam lingkungan kemiskinan, maka perilaku agresi mereka secara alami mengalami penguatan.

b. Anonimitas. Kotabesarseperti Jakarta, Bandung, Surabaya dan kota besar lainnya menyajikan berbagai suara, cahaya dan bermacam informasi yang besarnya sangat luar biasa. Orang secara otomatis cenderung berusaha untuk beradaptasi dengan melakukan penyesuaian diri terhadap rangsangan yang berlebihan tersebut. Terlalu banyak rangsangan indra dan kognitif membuat dunia menjadi sangat impersonal, artinya antara satu orang dengan orang lain tidak lagi saling mengenal atau mengetahui secara baik. Lebih jauh lagi, setiap individu cenderung menjadi anonim (tidak mempunyai identitas diri). Bila seseorang merasa anonim ia cenderung berperilaku semaunya sendiri, karena ia merasa tidak lagi terikat dengan norma masyarakat dan kurang bersimpati pada orang lain.

\section{Proses Pendisiplinan yang Keliru}

Pendidikan disiplin yang otoriter dengan penerapan yang keras terutama dilakukan dengan memberikan hukuman fisik, dapat menimbulkan berbagai pengaruh yang buruk bagi remaja. Pendidikan disiplin seperti itu akan membuat remaja menjadi seorang penakut, tidak ramah dengan orang lain, dan membenci orang yang memberi hukuman, kehilangan spontanitas serta inisiatif dan pada akhirnya melampiaskan kemarahannya dalam bentuk agresi kepada orang lain. Hubungan dengan lingkungan sosial berorientasi kepada kekuasaan dan ketakutan. Siapa yang lebih berkuasa dapat berbuat sekehendak hatinya. Sedangkan yang tidak berkuasa menjadi tunduk. Pola pendisiplinan tersebut dapat pula menimbulkan pemberontakan, terutama bila larangan-larangan yang bersanksi hukuman tidak diimbangi dengan alternatif lain yang dapat memenuhi kebutuhan yang mendasar (misal: dilarang untuk keluar main, tetapi di dalam rumah tidak diperhatikan oleh kedua orang tuanya karena kesibukan mereka) (Soedardjo \& Fadilla, 1990).

\section{Pelaku Bullying}

Pada tahun 2008 lalu, Yayasan Semai Jiwa Amini pernah melakukan survei terhadap 1.500 pelajar SMP dan SMA di Jakarta, Yogyakarta dan Surabaya. Menurut survei tersebut, 67\% responden menyatakan bahwa bullying pernah terjadi di sekolah mereka. Pelakunya adalah teman, kakak kelas, adik kelas, guru, kepala sekolah, hingga preman di sekitar sekolah. Hampir semua responden tidak pernah melaporkan bullying yang mereka terima atau mereka lihat. Data yang masuk ke Komisi Perlindungan Anak Indonesia (KPAI) per November 2009, menunjukkan hal yang sama. Setidaknya terjadi 98 kasus kekerasan fisik, 108 kekerasan seksual, dan 176 kekerasan psikis pada anak yang terjadi di lingkungan sekolah (http://bigloveadagio. wordpress.com/2010/08/09/kekerasan-bullying-disekolah/).

Kasus bunuh diri pelajar SMP di bagian awal tulisan ini adalah contoh dari akibat kasus bullying yang dilakukan oleh teman sekolah yang bisa jadi, para pelaku juga tidak menyadari akibat dari perbuatan mereka. Bullying dalam bentuk verbal dan psikis seperti mengejek dan mengolok-olok kadangkala memang dianggap sepele oleh pelaku maupun para guru, bahkan termasuk oleh korban, karena dampaknya tidak tampak secara langsung. Dampak verbal bullying memang bersifat psikologis dan emosional. Karakteristik korban yang lemah, pendiam, dan tidak pernah melawan kemudian menyebabkan aksi bullying tersebut berlangsung terus-menerus hingga akhirnya membuat korban tertekan dan depresi.

Selain dilakukan oleh teman, aksi bullying ternyata banyak dilakukan juga oleh guru. Data dari KPAI Selama Januari hingga April 2008 menunjukkan angka yang agak mengejutkan. Selama periode waktu tersebut, jumlah kasus kekerasan terhadap anak berusia 0 - 18 tahun di Indonesia terdata 95 kasus. Dari jumlah itu, persentase tertinggi, yaitu 39,6 persen, dilakukan oleh guru. Bentuk kekerasan yang dilakukan oleh guru bermacam-macam, mulai dari pencabulan, kekerasan fisik, kekerasan selama mengajar dan lain-lainnya (http://detektifromantika. wordpress.com/kekerasan-terhadap-anak/).

Penulis pernah menangani kasus klien pelajar yang lumayan cerdas dan pintar. Saat itu dia kelas 1 SMA. Anak tersebut mendapatkan nilai yang bagus pada semua mata pelajaran, kecuali matematika. Dia mengatakan sangat tidak suka matematika dan "merasa bodoh dalam semua pelajaran hitungmenghitung." Dalam sesi terapi, penulis akhirnya mengetahui bahwa akar masalah mengapa dia 
membenci pelajaran matematika dan "merasa bodoh dalam semua pelajaran hitung-menghitung" adalah karena pada waktu kelas 1 dan 2 SD, anak ini punya pengalaman diajar oleh ibu guru matematika yang sangat galak. Menurut deskripsi anak tersebut, setiap kali mengajar, ibu guru matematika itu selalu marah-marah dan membentak-bentak. Setiap kali berbicara, Ibu Guru itu mengeluarkan suara yang sangat keras dengan mata yang melotot. Ibu guru itu sering pula menghukum murid di depan kelas dan memukul kaki para murid dengan penggaris kayu yang besar. Anak tersebut pernah suatu ketika mendapatkan nilai nol saat ulangan. Angka nol itu ditulis besar-besar dengan pena berwarna merah di kertas ulangannya. Dia kemudian dihukum berdiri di depan kelas dan dipukul dengan penggaris. Bisa dipahami jika kemudian pelajaran matematika dan pelajaran menghitung lainnya seolah menjadi monster yang menakutkan. Sejak saat itu, setiap akan masuk jam pelajaran matematika, dirinya selalu merasa tegang dan cemas tanpa dia tahu penyebab sebenarnya. Dia juga selalu takut kepada semua guru matematika dari SD hingga SMA tanpa alasan yang jelas. Perasaan cemas dan takut itu terus muncul sampai dia bertemu dengan penulis.

\section{Dampak Bullying}

Sebagaimana disebutkan di awal bahwa dalam jangka pendek, bullying dapat menimbulkan perasaan tidak aman, terisolasi, perasaan harga diri yang rendah, depresi atau menderita stress yang dapat berakhir dengan bunuh diri. Dalam jangka panjang, korban bullying dapat menderita masalah emosional dan perilaku.

Efek jangka panjang bullying bisa jadi tidak disadari baik oleh pelaku, korban, maupun guru dan orangtua. Karena dampaknya lebih bersifat psikis dan emosi yang tidak terlihat dan prosesnya sangat perlahan, berlangsung lama dan tidak langsung muncul saat itu juga. Penulis sendiri memiliki pengalaman menarik yang membuktikan bahwa bullying bisa berakibat buruk bagi si korban dalam jangka panjang. Penulis pernah menangani klien lain yang menderita gangguan psikis dan perilaku. Klien penulis tersebut, sebut saja namanya Mia adalah seorang mahasiswi di sebuah perguruan tinggi swasta di Yogyakarta. Sebelum diterapi, Mia dilaporkan sering mengalami gejala seperti orang kesurupan dan setelah sadar dari kesurupannya, dia menjadi seperti mengalami amnesia. Dia lupa apa saja yang telah dilakukan dan siapa saja yang dia temui beberapa hari sebelumnya. Oleh dosennya, Mia disarankan untuk menjalani hypnotherapy dengan penulis. Pada saat pre-talk (semacam anamnesis dalam psikologi klinis untuk mengidentifikasi dan mendiagnosis masalah klien), diketahui bahwa Mia menderita fobia keramaian tanpa dia tahu secara pasti apa penyebabnya. Jika berada di tempat ramai atau banyak orang, dia langsung diserang rasa cemas (anxiety), pusing, dan mual sehingga dia selalu mencari tempat yang sepi untuk menyendiri. Dia juga memiliki rasa minder, suka menyendiri, mudah merasa tertekan, dan menderita amnesia temporal. Gangguan-gangguan inilah yang kemudian menyebabkan Mia menjadi seperti orang kesurupan.

Dalam proses pre-talk tersebut, anak ini mengeluhkan orangtuanya yang terlalu sibuk menghabiskan waktu untuk bekerja, sehingga hanya punya sedikit waktu tersisa untuk dia. Ketika SMP hingga SMA dia sering merasa marah kepada orangtuanya karena perhatian mereka yang dia rasa sangat kurang. Namun rasa marah itu selalu dipendam. Sampai di sini, penulis sempat berasumsi bahwa akar masalah Mia adalah kurang dekatnya hubungan dia dengan orangtuanya. Namun, pada saat terapi, ketika Mia berhasil dibawa masuk ke pikiran bawah sadar (deep trance) dan dilakukan regresi (dibawa kembali ke masa lampau), baru terungkap bahwa masalah psikis dan emosi anak tersebut disebabkan oleh bullying yang dilakukan teman-temannya pada saat dia duduk di kelas dua SMP.

Berdasarkan apa yang diungkapkannya, pada saat SMP, ada enam teman sekelas dia yang membentuk satu geng dan mereka sering melakukan bullying terhadapnya. Bullying yang dialami Mia lebih banyak dalam bentuk verbal dan mental seperti mengejek, mencemooh, mengolok-olok, memaki, mengancam dan mengintimidasi. Bentuk lainnya adalah pengucilan. Beberapa teman Mia yang mencoba mendekati Mia, turut diejek dan diintimidasi oleh anggota geng tersebut, sehingga Mia seringkali tidak punya teman bermain saat di sekolah.

Semua itu berlangsung hampir setiap hari selama Mia duduk di kelas 2 SMP. Ketika penulis menanyakan mengapa mereka melakukan hal itu, Mia menjawab tidak tahu. Dia juga tidak pernah melaporkan dan menceritakan kepada siapapun 
tentang apa yang ia alami, baik kepada teman, guru maupun orangtuanya. Dia hanya memendam semua perasaannya karena takut, malu dan tidak tahu harus bercerita kepada siapa. Bisa dibayangkan betapa menderitanya Mia saat itu. Di sekolah hampir tidak punya teman yang benar-benar dekat, hampir setiap hari mendapatkan intimidasi oleh beberapa teman sekelasnya, dan orangtuanya jarang punya waktu yang cukup untuknya saat di rumah.

Setelah semua proses terapi selesai dan emosiemosi negatif akibat perilaku bullying temanteman sekolahnya berhasil dihilangkan, gangguangangguan psikis dan emosi yang dialami Mia pun berkurang. Sebulan sesudah terapi, Mia mengabarkan bahwa kondisi dia sudah baik, kuliah lancar, amnesia sembuh dan sudah tidak kesurupan-kesurupan lagi. Penulis akhirnya meyakini dengan pasti bahwa gangguan-gangguan psikis dan emosi yang dialami Mia ini lebih banyak disebabkan oleh bullying yang dilakukan oleh teman-teman sekolahnya, khususnya saat ia duduk di bangku SMP.

Ketika penulis menceritakan apa yang dia ungkapkan saat proses terapi, Mia baru mengingat bahwa ejekan-ejekan yang dilakukan temantemannya, terutama saat SMP, berlangsung sangat intens dan berulang-ulang hampir setiap hari. Ejekanejekan dan semua situasi yang merangkai peristiwa saat itu akhirnya masuk ke dalam pikiran bawah sadar Mia dan membentuk sebuah program berupa "banyak orang-keramaian-diejek-dipermalukanmarah-sakit hati". Inilah yang kemudian memicu fobia keramaian yang dialami Mia. Akibatnya, setiap kali dia berada di tempat di mana ada banyak orang di sana, program "banyak orang-keramaiandiejek-dipermalukan-marah-sakit hati" itu akan aktif sehingga tanpa sebab yang jelas, dia langsung merasa cemas, takut, pusing dan mual.

Bagaimana dengan amnesia yang dialami Mia? Ketika diejek dan dikucilkan oleh teman-teman geng kelasnya tanpa alasan yang tidak dia ketahui pasti, dia tidak berani melawan dan hanya memendam rasa takut dan marah yang dirasakannya. Kondisi tersebut berlangsung berulang-ulang dalam waktu yang relatif lama. Ada ungkapan, repetition is the mother of skill. Pengulangan adalah kunci dari skill, baik itu skill yang positif maupun skill yang negatif. Mia dalam hal ini belajar menguasai 'skill' memendam perasaan. Pada dasarnya, memendam dan mengubur perasaan ini adalah mekanisme pertahanan diri (self defense mechanism) agar perlakuan tidak enak itu tidak menimbulkan rasa sakit. Pada akhirnya, skill memendam perasaan itu semakin kuat, sehingga input-input eksternal yang sebenarnya tidak mengancam pun ikut pula terpendam. Akhirnya Mia menjadi seperti amnesia, mudah melupakan hal-hal yang baru saja dilakukannya.

Dalam psikologi klinis, gangguan phobia, cemas dan gejala seperti amnesia yang dialami Mia ini disebut dengan istilah Post Traumatic Stress Disorder (PTSD). Di negara-negara maju seperti AS, penelitian-penelitian mengenai PTSD menemukan bahwa bullying yang dialami semasa duduk di bangku sekolah sangat erat kaitannya dengan munculnya beberapa kasus Complex PTSD pada saat dewasa. Dr. Charles Rasion, seorang psikiater dari Emory University Medical School, AS, dalam penelitiannya menemukan bahwa bullying di sekolah dapat menyebabkan terjadinya PTSD pada saat dewasa. Lebih lanjut, Raison menyatakan bahwa perempuan dua kali lebih beresiko menderita PTSD pada saat dewasa akibat bullying pada saat sekolah daripada laki-laki (http://edition.cnn. com/2009/HEALTH/expert.q.a/03/31/bullying.ptsd. raison/index.html). Data ini semakin meyakinkan penulis bahwa gangguan yang dialami Mia adalah gejala PTSD akibat bullying yang dialaminya pada saat sekolah.

Apa yang dialami Mia adalah salah satu contoh nyata dari dampak jangka panjang korban bullying yang jika tidak ditangani akan terbawa hingga dewasa dan tentu akan mengganggu pencapaian-pencapaian terbaik dalam kehidupan mereka, baik dalam studi, karir, hubungan sosial dan akhirnya kebahagiaan hidup mereka. Hal terbaik yang seharusnya dilakukan adalah menangani dan mencegah perilaku bullying ini sejak dini, di sekolah dan di rumah.

\section{Mencegah Bullying}

Ada beberapa hal yang bisa dilakukan untuk mencegah bullying: Pertama, mengubah cara mendidik dan cara memperlakukan siswa. Diakui atau tidak, perilaku siswa sebagiannya adalah representasi dari cara guru dalam mendidik dan memperlakukan mereka. Jika perilaku siswa buruk (termasuk di dalamnya tindakan bullying), maka pasti ada sesuatu yang kurang dari metode yang digunakan guru dalam mendidik dan memperlakukan mereka.

Penulis teringat dengan seorang Guru BK 
sebuah sekolah menengah di salah satu kota di Jawa Tengah yang tampak sangat akrab dengan para siswanya. Dari yang paling berandalan sampai yang paling penurut, semua bisa dekat dengan Ibu Guru tersebut. Mereka semua juga nurut dengan nasihatnasihatnya. Ketika penulis bertanya apa metode dan pendekatan yang Ia gunakan? Ia dengan bersahaja menjawab, bahwa Ia tidak pernah mencela atau memberi label yang buruk terhadap murid, bahkan meskipun mereka melakukan kesalahan yang berat sekalipun. Sebaliknya, Ia selalu menanamkan katakata dan kalimat-kalimat positif setiap hari kepada setiap murid. Misal: "kamu itu sebenarnya anak yang baik" atau "kamu adalah anak yang baik."

Ia terus melakukan dan mengatakan kalimat seperti itu dengan tulus dan akrab kepada semua muridnya. Jika dilakukan secara berulang-ulang setiap hari secara konsisten, kalimat positif tersebut pelan-pelan akan terserap dan tertanam dalam pikiran bawah sadar para murid. Jika kalimat positif tersebut benar-benar telah tertanam dalam pikiran bawah sadar, si murid akan mendapati dan menyadari bahwa dirinya sebenarnya adalah anak yang baik, dan secara otomatis segala pilihan perilaku dan sikapnya akan baik pula. Sebaliknya, jika kalimatkalimat yang masuk dalam pikiran bawah sadar si murid setiap harinya adalah celaan-celaan, penilaian-penilaian dan penghakiman-penghakiman yang negatif, terlebih semua itu berasal dari guru, maka hal-hal negatif itulah yang akan tertanam dan terprogram dalam bawah sadarnya. Jika demikian yang terjadi, maka segala pilihan perilaku, sifat dan sikap si murid pun akan negatif pula, termasuk kekerasan dan bullying. Terbukti, siswa-siswa yang berada dalam bimbingan Ibu Guru tersebut sangat jarang terlibat masalah yang serius, baik dengan sekolah, guru-guru lain, teman sekolah maupun orangtua.

Hasil penelitian pun mendukung hal tersebut. Penelitian yang dilakukan oleh Ratna Juwita, seorang Psikolog di Universitas Indonesia (UI) Jakarta terhadap siswa-siswi SD, SMP dan SMA di tiga kota besar di Indonesia menunjukkan bahwa sekolah dengan tingkat bullying paling rendah adalah sekolah yang terdapat hubungan yang sangat baik dan akrab antara guru dan siswa (http://stopbullyingbyseven. blogspot.com/).

Pendekatan positif lainnya yang bisa dilakukan guruadalahmemberipenghargaan(apresiasi)terhadap setiap usaha siswa - baik untuk aktivitas kurikuler maupun non-kurikuler - apapun dan bagaimana pun hasilnya. Jangan pernah menyalahkan para murid dan hindari memberikan hukuman. Selalu berikan penilaian yang positif, bahkan meskipun hasil mereka buruk. Pendekatan ini barangkali terkesan aneh bagi mereka yang terbiasa dengan budaya menghukum (punishment) ketika murid melakukan kesalahan, karena diyakini murid akan terus melakukan kesalahan jika mereka tidak diberi hukuman. Riset mutakhir tentang kekuatan pikiran, termasuk dalam aplikasinya di dunia pendidikan, menunjukkan bahwa hukuman ternyata bisa menghambat daya pikir kreatif dan bisa meningkatkan agresi. Sedangkan pujian, penghargaan dan dorongan yang positif (encouragement) dapat merangsang kreativitas dan perilaku positif. Jika iklim dan hubungan positif antara para siswa dan para guru ini benar-benar bisa terbangun dengan baik, bullying dengan sendirinya akan berkurang.

Kedua, bangun jejaring komunikasi yang aktif dengan para orangtua (Kohut, 2007: 167). Berilah orangtua informasi yang up-to-date mengenai perkembangan kegiatan sekolah dan anak mereka di sekolah. Jika perlu, sekolah idealnya memiliki bagian khusus yang menangani komunikasi dengan orangtua. Selama ini, komunikasi antara sekolah dan orangtua hanya pada saat akhir semester, pembagian rapor, dan atau kenaikan kelas. Sudah saatnya pola komunikasi ini ditingkatkan kualitasnya. Banyak yang bisa dilakukan sebagai media komunikasi antara guru dan orangtua. Misal, membuka hotline sekolah yang bisa dihubungi orangtua setiap saat, website yang interaktif, atau majalah rutin berkala. Peningkatan kualitas komunikasi setidaknya bisa meningkatkan partisipasi dan kedekatan orangtua dengan sekolah, yang pada akhirnya juga adalah kedekatan komunikasi antara orangtua dan anakanak mereka. Komunikasi aktif semacam ini jika terbangun akan bisa mengurangi bullying, dan atau mengurangi dampaknya. Ingat, salah satu variabel pendukung dari masalah yang dialami Mia adalah kurangnya komunikasi antara dia dengan orangtuanya, sehingga Mia tidak bisa menceritakan apa yang dialaminya di sekolah.

Ketiga, pemberian pemahaman yang tepat mengenai bullying terhadap para guru, siswa dan orangtua melalui workshop, pelatihan-pelatihan atau seminar-seminar. Pemberian pemahaman ini bisa berupa materi tentang karakteristik bullying, pencegahan dan penanganannya. Dengan demikian, 
para guru dapat mengantisipasi dan mengidentifikasi perilaku bullying para siswa (Kohut, 2007:167).

Keempat, deklarasikan kampanye antibullying yang melibatkan peran aktif semua unsur sekolah, dari para guru, karyawan, siswa, dan para orangtua. Kampanye ini bisa berupa poster-poster anti-bullying, pertunjukan-pertunjukan seni, atau apapun yang tema sentralnya adalah anti-bullying. Cara ini, selain untuk mencegah perilaku bullying dan memberikan pemahaman arti bullying terhadap semua unsur sekolah, juga bisa berfungsi sebagai media pengalihan energi dan sumber daya murid untuk hal-hal yang positif.

Kelima, sebagai pencegahan sekaligus sebagai penanganan kasus bullying, sekolah perlu menyediakan semacam bullying center bagi para siswa. Bimbingan Konseling di sekolah bisa juga ditambahkan fungsi ini. Bagian ini berperan sebagai tempat pengaduan yang sangat rahasia, artinya identitas korban pelapor akan dirahasiakan. Bagian ini juga berperan memberikan konseling dan terapi bagi siswa korban maupun pelaku bullying.

\section{Penutup}

Dalam undang-undang perlindungan anak No.23 Tahun 2002 pasal 54 dinyatakan, "anak di dalam dan di lingkungan sekolah wajib dilindungi dari tindakan kekerasan yang dilakukan oleh guru, pengelola sekolah atau teman-temannya di dalam sekolah yang bersangkutan, atau lembaga pendidikan lainnya." Undang-undang perlindungan anak di atas dengan tegas telah menyebutkan mandat yang harus dipenuhi, yakni melindungi anak-anak di sekolah dari semua macam tindak kekerasan. Bullying, sebagai salah satu bentuk tindak kekerasan yang bisa mengancam perkembangan anak di masa depan, selayaknya mendapat perhatian yang lebih dari para guru, orangtua, para murid sendiri dan terlebih lagi pemerintah.

Upaya pencegahan dan penanganan bullying yang lebih serius perlu untuk dilakukan. Karena selama ini upaya anti-bullying masih dilakukan secara sporadis oleh LSM atau NGO serta individuindividu yang efektivitas dan keberhasilannya tidak terlalu besar. Demikian juga dengan kontribusi dari kalangan akademik untuk menyediakan data yang lebih akurat dan penanganan yang berbasis data empiris perlu digiatkan lagi. Tulisan ini adalah salah satu upaya awal menuju aksi-aksi tersebut.
Karena jika tidak segera dilakukan aksi-aksi yang lebih serius dan terorganisir, bullying ini akan mereproduksi tindakan kekerasan yang ada di sekolah. Karena pelaku akan cenderung mengulang perbuatannya dan korban bullying pun memiliki kecenderungan yang sangat besar untuk melakukan tindakan bullying pula jika ada kesempatan.

\section{Daftar Pustaka}

\section{Buku dan Jurnal}

Olweus, Dan. 1993. Bullying at School: What We Know and What We Can Do. Massachussetts: Blackwell Publishing.

Hall, Calvin S., \& Gardner Lindzey. 1993. Psikologi Kepribadian 1: Teori-teori Psikodinamik (Klinis). Yogyakarta: Kanisius.

Baron, Donn, \& Robert A. Byrne. 1994. Social Psychology. NV, USA: Allyn \& Bacon.

Soedardjo dan Helmi Avin Fadilla. Beberapa Perspektif Perilaku Agresi. Buletin Psikologi. Tahun VI, No. 2 Desember 1998.

Davidoff, Ronald, et. al. Aggression and Counter Aggression during Child Psychiatric Hospitalization. Journal of the American Academy of Child and Adolescence Psychiatry. Vol. 29, Issue 2. March 1990.

Kohut, Margaret R. 2007. The Complete Guide to Understanding, Controlling and Stopping Bullies \& Bullying: a Complete Guide for Teachers and Parents. Florida: Atlantic Publishing.

\section{Internet}

Indonesian Anti-Bullying. http://id.wordpress.com/ tag/bullying/. Diakses pada 18 Mei 2011.

Budaya Bullying di Sekitar Kita. http://mfahmia2705. blogspot.com/2007/06/budaya-bullying-disekitar-kita.html

Kekerasan Bullying di Sekolah. http://bigloPerilaku Prososial vs Kekerasan Sosial: 